\title{
Carbonate dissolution in copepod guts: a numerical model
}

\author{
Heiko Jansen*, Dieter A. Wolf-Gladrow
}

Alfred Wegener Institute for Polar and Marine Research, PO Box 120161, 27515 Bremerhaven, Germany

\begin{abstract}
A numerical model is proposed for investigating the potential of calcium carbonate dissolution in copepod guts. A sensitivity analysis is performed to reveal critical parameters. Gut $\mathrm{pH}$ sets the dissolution rate and gut-clearance rate determines the time scale on which ingested calcite is subject to dissolution. Highest dissolution is obtained when the individual zooplankton is alternating between grazing and non-grazing and feeding is restricted to the night-time period. Model results show that up to $70 \%$ of the ingested carbonate may be dissolved in the guts, considering reingestion of faecal pellets in the absence of a phytoplankton bloom, while $\sim 15 \%$ dissolution is to be expected in a bloom situation. An estimate is made for the contribution of calcite dissolution in copepod guts to the proposed global calcite loss in the water column.
\end{abstract}

KEY WORDS: Calcium carbonate dissolution $\cdot$ Copepod guts $\cdot$ Faecal pellets

\section{INTRODUCTION}

In a recent paper, Milliman et al. (1999) proposed that more than $60 \%$ of biogenically produced carbonate dissolves in the upper $1000 \mathrm{~m}$ of the water column. One process that may contribute to this is the dissolution of $\mathrm{CaCO}_{3}$ in zooplankton guts. The guts of copepods, for example, can be sufficiently acidic to cause carbonate dissolution. Calcareous phytoplankton such as coccolithophorids are grazed by copepods, the predominant form of Crustacea (Pilskaln \& Honjo 1987, Ishimaru et al. 1988). Calanoid copepods are present in all marine environments and usually make up $\geq 70 \%$ by mass of all net-collected zooplankton (Lalli \& Parsons 1993, p. 88). Evidence for copepod grazing on Emiliania huxleyi was given by van der Wal et al. (1995), who observed large amounts of coccoliths in copepod faecal pellets. In a recent study of Arabian Sea copepods, thin sections of the guts of 17 specimens of the genus Spinocalanus contained 10 to $30 \%$ coccoliths (M. Gowing pers. comm.).

${ }^{*}$ Present address: Meteorologisches Institut der Universität Hamburg, Bundesstraße 55, 20146 Hamburg, Germany.

E-mail: heiko.jansen@dkrz.de
It has been proposed that copepods are able to regulate gut $\mathrm{pH}$ to enhance enzymatic activity (Mayzaud \& Mayzaud 1981). The optimal $\mathrm{pH}$ for a variety of copepod digestive enzymes ranges from 4 to 9 (Mayzaud 1986). With decreasing $\mathrm{pH}$, the carbonate system is increasingly undersaturated with respect to calcite; thus the coccoliths ingested are subject to dissolution. Pond et al. (1995) measured $\mathrm{pH}$ values in guts of starved individuals of Calanus helgolandicus between 6.9 and 7.2, whereas the gut $\mathrm{pH}$ of copepods of the same species feeding on coccolithophorids ranged from 8.0 to 8.2. We are not aware of measurements on other Calanus species or of measurements of their gut $\mathrm{pH}$ in the field.

To the authors' knowledge, modelling work on carbonate dissolution in zooplankton guts has hitherto not been pursued. Field work has provided contrary evidence for carbonate dissolution in zooplankton guts, as faecal pellets contain unbroken coccoliths which show no sign of dissolution (Honjo \& Roman 1978, Bathmann et al. 1987). Van der Wal et al. (1995), however, in a study of an Emiliania huxleyi bloom between the Shetland Islands and Norway, found copepod faecal pellets that almost exclusively contained fragmented coccoliths. We believe that the evidence of unbroken coccoliths does not exclude dissolution in copepod guts. 
Table 1. Parameters describing zooplankton gut model

\begin{tabular}{|c|c|c|c|c|}
\hline Parameter & Symbol & Range & Standard value & Source \\
\hline Ingestion rate of $\mathrm{C}_{\text {org }}$ & - & $0-50 \mu \mathrm{g} \mathrm{C} \mathrm{d}{ }^{-1}$ & $5 \mu \mathrm{g} \mathrm{C} \mathrm{d}{ }^{-1}$ & Båmstedt et al. (1999) \\
\hline Ingestion rate of $\mathrm{CaCO}_{3}$ & $I$ & $0-5 \mu \mathrm{g} \mathrm{C} \mathrm{d}{ }^{-1}$ & $0.5 \mu \mathrm{g} \mathrm{C} \mathrm{d}^{-1}$ & $\begin{array}{l}\text { Nejstgaard et al. (1994) } \\
\text { Huskin et al. (2000) }\end{array}$ \\
\hline Gut-passage time & $K^{-1}$ & $12-85 \min$ & $30 \mathrm{~min}$ & $\begin{array}{l}\text { Irigoien (1998), } \\
\text { Dam \& Peterson (1988) }\end{array}$ \\
\hline Gut volume & $V$ & $1-8 \times 10^{-9} 1^{\mathrm{a}}$ & $7 \times 10^{-9} 1$ & Harris (1994) \\
\hline $\mathrm{CaCO}_{3}$ dissolution-rate constant & $\kappa$ & $3-7 d^{-1}$ & $5 \mathrm{~d}^{-1}$ & Keir (1980) \\
\hline $\mathrm{CaCO}_{3}$ dissolution-rate order & $\eta$ & $1-5$ & 4.5 & Keir (1980) \\
\hline Critical carbonate concentration & {$\left[\mathrm{CO}_{3}{ }^{2-}\right]_{\mathrm{c}}$} & & $42.7 \mu \mathrm{mol} \mathrm{kg}{ }^{-1}$ & Millero (1995) \\
\hline Bulk sea water DIC & $\Sigma \mathrm{CO}_{2}$ & & $2000 \mu \mathrm{mol} \mathrm{kg}{ }^{-1 \mathrm{~b}}$ & Takahashi et al. (1981) \\
\hline Bulk sea water alkalinity & TA & & $2300 \mu \mathrm{mol} \mathrm{kg}{ }^{-1 \mathrm{~b}}$ & Takahashi et al. (1981) \\
\hline
\end{tabular}

Indications exist that coccoliths are protected against dissolution by an organic membrane (Watabe \& Kingsley 1990, Fagerbakke et al. 1994). As long as the coccoliths are complete, they thus escape dissolution, while a broken coccolith may be dissolved very effectively. Hence, the observation of complete, undissolved coccoliths is not necessarily contradictory to dissolution inside faecal pellets or copepod guts.

\section{THE MODEL}

The proposed model is formulated for copepods. It assumes the gut to be one box with influx and efflux. It features calcite $\mathrm{C}$ content $(C, \mu \mathrm{mol})$ and alkalinity

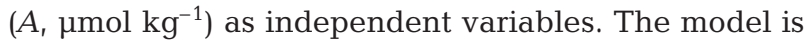
consistent with the proposition of Penry \& Jumars (1986) and Jumars \& Penry (1989) that guts be viewed as chemical reactors. By their classification, our model uses a continuous-flow, stirred tank reactor (CSTR), which incorporates a constant flow of material through the gut and complete mixing within it. $\mathrm{pH}$ is a fixed value, and together with alkalinity determines the carbonate system (Millero 1995), i.e. dissolved inorganic carbon $\left(\sum \mathrm{CO}_{2}\right)$ and $\left[\mathrm{CO}_{3}{ }^{2-}\right]$, the latter being ultimately responsible for the saturation state with respect to calcite. For the calculation of $\left[\mathrm{CO}_{3}{ }^{2-}\right]$ from $\mathrm{pH}$ and alkalinity, the dissociation constants given by Zeebe (2001) have been used. The model's equations are as follows:

$$
\begin{aligned}
& \frac{\mathrm{d} C(t)}{\mathrm{d} t}=I-(f(t)+K) C(t) \\
& \frac{\mathrm{d} A(t)}{\mathrm{d} t}=K A_{\text {bulk }}-K A(t)+2 \frac{f(t) C(t)}{10^{3} V(t)}
\end{aligned}
$$

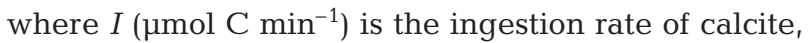
$K\left(\mathrm{~min}^{-1}\right)$ is the gut clearance rate and $f(t)\left(\mathrm{min}^{-1}\right)$ is the fraction of carbonate dissolving per minute at time $t$, $A_{\text {bulk }}$ is the alkalinity of bulk seawater, and $V(t)\left(\mathrm{m}^{3}\right)$ is the effective gut volume, i.e. total gut volume minus particulate contents. Dissolution of $\mathrm{CaCO}_{3}$ depends on possible undersaturation with respect to calcite in the gut via:

$$
f(t)= \begin{cases}\kappa(1-\Omega(t))^{\eta} & \text { if } \Omega(t)<1, \\ 0 & \text { if } \Omega(t) \geq 1\end{cases}
$$

where $\kappa$ is the dissolution-rate constant $\left(\mathrm{min}^{-1}\right)$ and $\eta$ is the dissolution-rate order. The saturation state $\Omega(t)$ is given by the quotient of $\left[\mathrm{CO}_{3}{ }^{2-}\right]$ in the gut and the critical carbonate concentration, $\left[\mathrm{CO}_{3}{ }^{2-}\right]_{\mathrm{C}}$, the latter being depth-dependent due to pressure effects:

$$
\Omega(t)=\frac{\left[\mathrm{CO}_{3}{ }^{2-}\right](t)}{\left[\mathrm{CO}_{3}{ }^{2-}\right]_{C}}
$$

We assumed a surface ocean value for $\left[\mathrm{CO}_{3}{ }^{2-}\right]_{\mathrm{c}}$ at $100 \mathrm{~m}$ depth of $42.7 \mu \mathrm{mol} \mathrm{kg}{ }^{-1}$ (Millero 1995). Standard values for the parameters are given in Table 1. As observations of ingestion rates of organic carbon are much more abundant than for uptake rates for calcite particles, we assume a certain fraction of organic carbon uptake for calcite ingestion. In feeding experiments, Harris (1994) reported that $\mathrm{CaCO}_{3}$ uptake amounted to $35-40 \%$ of organic carbon ingested. We use a lower value of $10 \%$, reflecting the fact that in the field the food supply is very heterogeneous and copepods take up more organic carbon via noncalcareous phytoplankton than in culture experiments, where they are selectively fed with coccolithophorids. The calculated ingestion rates of calcite conform to those found by Huskin et al. (2000) for Calanus helgolandi- 
cus, whereby significant ingestion was observed only when food supply was high. Huskin et al. (2000) reported an ingestion rate of $0.2 \mu \mathrm{g} \mathrm{C}$ ind. ${ }^{-1} \mathrm{~d}^{-1}$ at an Emiliania huxleyi concentration of $161 \mu \mathrm{g} \mathrm{C} \mathrm{dm}{ }^{-3}$. This food concentration is much higher than those found in the field. An $E$. huxleyi density of $10^{6}$ cells $\mathrm{dm}^{-3}$, which van der Wal et al. (1995) observed in coccolithophorid blooms, yields an organic carbon concentration of $10 \mu \mathrm{g} \mathrm{C} \mathrm{dm}^{-3}$. However, Huskin et al. (2000) mentioned that their results for E. huxleyi might be underestimations due to seasonal mismatch, a problem which is also discussed by Nejstgaard et al. (1995). In a mesocosm study, Nejstgaard et al. (1994) analyzed grazing of $C$. finmarchicus on an E. huxleyi bloom. In the prebloom situation with low prey concentrations, they calculated an uptake of $0.26 \mu \mathrm{g} \mathrm{C}$ ind. ${ }^{-1} \mathrm{~d}^{-1}$, which increased to $3 \mu \mathrm{g} \mathrm{C}$ ind. ${ }^{-1} \mathrm{~d}^{-1}$ during the bloom. Significantly higher ingestion rates were found by Nejstgaard et al. (1997) in a further mesocosm study, in which they calculated uptake rates of $0.1 \mu \mathrm{g} \mathrm{C}$ ind. ${ }^{-1} \mathrm{~d}^{-1}$, which increased to $19 \mu \mathrm{g} \mathrm{C}$ ind..$^{-1} \mathrm{~d}^{-1}$ during the bloom.



Fig. 1. $\mathrm{CaCO}_{3}$ dissolution potential assuming gut-passage time of 30 min and the following dissolution kinetics: $\mathrm{d} C / \mathrm{d} t=-\kappa(1-\Omega)^{\mathrm{n}}$, continuous line, $\kappa=3 \mathrm{~d}^{-1}, \mathrm{n}=4.5$ (Keir 1980; lower boundary for coccolithophorids); dashed line, $\kappa=7 \mathrm{~d}^{-1}, \mathrm{n}=4.5$ (Keir 1980; upper boundary for coccolithophorids); dotted line, $\kappa=1 \mathrm{~d}^{-1}, \mathrm{n}=2.9$ (Walter \& Morse 1985); dash-dotted line, $\mathrm{\kappa}=0.38 \mathrm{~d}^{-1}, \mathrm{n}=1.0$ (Hales \& Emerson 1997); where $\kappa=$ dissolution-rate constant

\section{RESULTS AND DISCUSSION}

\section{Constant grazing}

Our first approach was to assume constant grazing with a gut-passage time of $30 \mathrm{~min}$ (Irigoien 1998). We applied the set of parameters in Table 1, and varied $\mathrm{pH}$ from 5 to 8 . The fraction of calcite dissolved was calculated as the difference between uptake and egestion. Calculations yielded no dissolution for $\mathrm{pH} \geq 7.5$. The maximal amount of $\mathrm{CaCO}_{3}$ dissolved was $\sim 6 \%$ at $\mathrm{pH} 5$. Thus, with constant grazing, no significant dissolution was evident. This may be due to the short gut-passage time compared to the rather slow dissolution kinetics (Fig. 1). Because of the very small volume of the gut, dissolution of $\mathrm{CaCO}_{3}$ massively perturbs the carbonate system, removing any undersaturation very quickly, thus counteracting any significant dissolution. This effect has not been considered in Fig. 1, which thus illustrates an ideal upper limit of the amount of calcite that may be dissolved in $30 \mathrm{~min}$.

\section{Alternating grazing and non-grazing}

We then tested the effect of alternating grazing and non-grazing. In this scenario, ingested calcite could also be dissolved during the longer non-grazing interval, during which the calcite stock was not replen- ished. We tried various combinations of grazing/nongrazing cycles, considering short gut-passage times during grazing $\left(K_{\mathrm{g}}^{-1}=30 \mathrm{~min}\right)$ and long passage times during non-grazing intervals $\left(K_{\mathrm{n}}^{-1}=\right.$ minimum \{length of non-grazing time, $4 \mathrm{~h}\}$ ). Atkinson et al. (1996) observed gut-passage times of up to $4 \mathrm{~h}$ for diurnally migrating copepods. Fig. 2 shows a $24 \mathrm{~h}$ period of a model run alternating 140 min grazing with $30 \mathrm{~min}$ non-grazing. At the beginning of a grazing cycle, the calcite stock inside the gut increased strongly. Dissolution set in, raising the saturation state also. At the end of a grazing cycle, uptake of calcite and loss due to dissolution and egestion was almost in balance, so the standing stock was nearly constant. As grazing stopped, calcite was egested rapidly and, dissolution strength decreased, as did saturation.

The results of model runs varying $\mathrm{pH}$ and ingestion rate with a 30/120 min grazing/non-grazing cycle are given in Table 2. The uptake rates of $\mathrm{CaCO}_{3}$ cover the range given by Harris (1994, his Table 3). The fraction of calcite dissolved was calculated as the difference between uptake and egestion during one grazing/nongrazing cycle. With a low ingestion rate, a moderate amount (up to $\sim 19 \%$ ) of the ingested calcite may be dissolved inside the gut. Obviously, dissolution efficiency increases with decreasing $\mathrm{pH}$. Also, as the $\mathrm{pH}$ is lowered, the influence of the ingestion rate diminishes. Table 3 shows results at $\mathrm{pH} 6$ and 5 when the nongrazing time was increased. The length of the non- 



Fig. 2. Alternating grazing/non-grazing modes. $\mathrm{pH}$ set at 6 , and length of grazing/non-grazing cycle $=140 / 30 \mathrm{~min}$. Top graph: calcite standing stock in gut; middle graph: dissolved inorganic carbon (continuous line), and total alkalinity (dashed line); bottom graph: saturation state ton and zooplankton food are spatially highly variable (Davis et al. 1996, Gallager et al. 1996, Norrbin et al. 1996, Greene et al. 1998). Furthermore, some zooplankton undergo diurnal migrations, which could result in zero food intake for several hours (Dagg et al. 1989, Atkinson et al. 1996). Even in the presence of a coccolithophorid bloom, it makes sense for a copepod not to graze constantly. Firstly, after a short time its digestive tract would be full; continuing to graze would reduce its effectivity in digesting the food. Secondly, a bloom site is rather a dangerous place for the copepod to be, as blooms also attract predators; thus, it would be more favourable to move somewhere else to digest. Microcinemato-graphic studies (Rosenberg 1980, Cowles \& Strickler 1983) have shown that copepods alternate brief bouts of slow swimming and feeding with intervals during which swimming and feeding cease. There is also evidence that copepods reduce or interrupt their grazing for periods of up to a few hours in response to previous feeding success (Mackas \& Burns 1986). grazing cycle mainly determines the fraction of calcite dissolved, as it determines the time the carbonate particles are subject to dissolution inside the gut. For very long non-grazing periods of $12 \mathrm{~h}$, a maximal dissolution efficiency of $29 \%$ was reached. The impact of varying grazing and non-grazing interval lengths up to $4 \mathrm{~h}$ at pH 6 and 5 is shown in Fig. 3. At pH 5, dissolution of up to $23 \%$ of the ingested $\mathrm{CaCO}_{3}$ was possible. This much higher value compared to the constantgrazing scenario can be explained by long gut-passage times during non-grazing, i.e. the coccoliths are subjected to dissolution for a prolonged period during which no additional calcite is taken up.

Long non-grazing times are not unusual, as food availability in the field is very heterogeneous. New in situ methods have shown that patch sizes of zooplank-

Table 2. Results of model runs using a 30/120 min grazing/ non-grazing cycle. Dissolved fraction is heavily dependent on $\mathrm{pH}$

\begin{tabular}{|lcccc|}
\hline \multirow{2}{*}{$\begin{array}{l}\mathrm{CaCO}_{3} \text { uptake } \\
\left(\mu \mathrm{C} \mathrm{d}^{-1}\right)\end{array}$} & $\mathrm{pH} \mathrm{4}$ & \multicolumn{3}{c|}{$\mathrm{CaCO}_{3}$ loss (\%) } \\
\hline 0.5 & 19.4 & 17.3 & $\mathrm{pH} \mathrm{6}$ & $\mathrm{pH} \mathrm{7}$ \\
\hline 1.0 & 19.2 & 15.5 & 5.9 & 0.9 \\
1.5 & 18.9 & 14.1 & 4.6 & 0.6 \\
2.0 & 18.7 & 13.0 & 3.8 & 0.3 \\
2.5 & 18.4 & 12.0 & 3.2 & 0.3 \\
\hline
\end{tabular}

Table 3. Fraction (\%) of calcite dissolved as a function of grazing $(\mathrm{G})$ and non-grazing (N-G) interval length (min). Standard parameter values used, with $\mathrm{pH} 6$ and 5. Gut-passage time $=30$ min during grazing and maximal $4 \mathrm{~h}$ during nongrazing

\begin{tabular}{|lrrr|}
\hline N-G & $\mathrm{G}=30$ & $\mathrm{G}=60$ & $\mathrm{G}=90$ \\
\hline 30 min & & & \\
pH 6 & 5.2 & 4.7 & 4.4 \\
pH 5 & 8.7 & 8.5 & 8.4 \\
60 min & & & \\
pH 6 & 6.6 & 5.4 & 4.9 \\
pH 5 & 12.0 & 10.4 & 9.8 \\
120 min & & & \\
pH 6 & 8.5 & 6.4 & 5.6 \\
pH 5 & 17.3 & 13.6 & 12.0 \\
240 min & & & \\
pH 6 & 10.8 & 7.6 & 6.4 \\
pH 5 & 24.9 & 18.4 & 15.3 \\
360 min & & & \\
pH 6 & 12.6 & 8.7 & 7.2 \\
pH 5 & 26.9 & 19.9 & 16.4 \\
480 min & & & \\
pH 6 & 13.9 & 9.4 & 7.7 \\
pH 5 & 27.9 & 20.6 & 17.0 \\
600 min & & & \\
pH 6 & 14.8 & 10.0 & 8.1 \\
pH 5 & 28.4 & 21.0 & 17.3 \\
720 min & & & \\
pH 6 & 15.4 & 10.4 & \\
pH 5 & 28.7 & 21.2 & \\
& & & \\
& & & \\
\hline
\end{tabular}



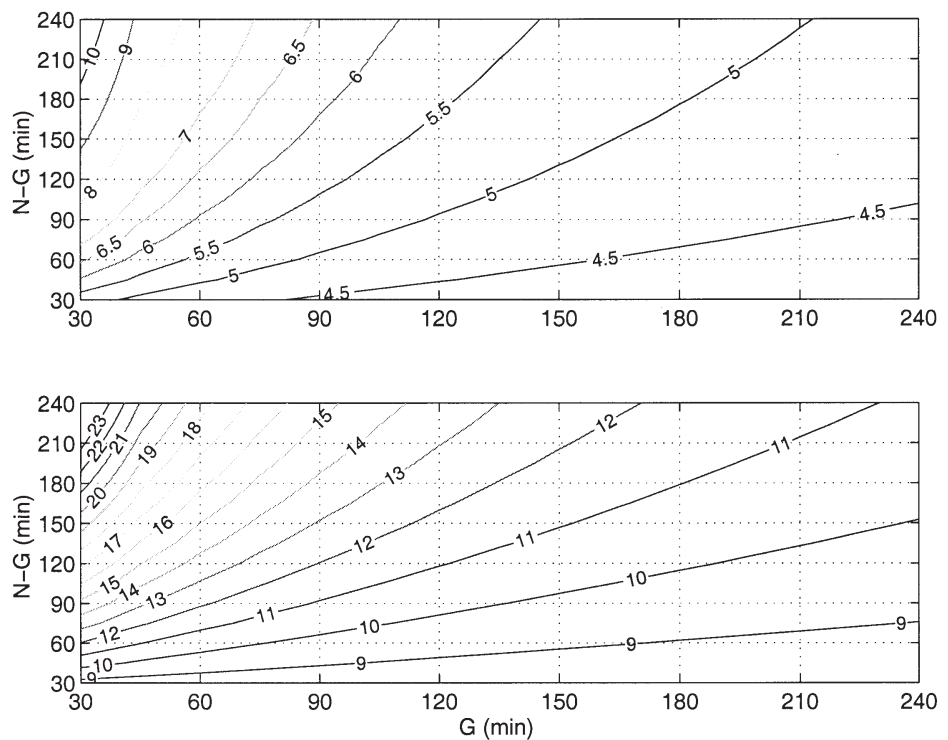

Fig. 3. Fraction (\%) of ingested calcite dissolved as a function of grazing (G) and non-grazing (N-G) interval length (min). Constant $\mathrm{pH}$ : top graph $\mathrm{pH} 6$, bottom graph $\mathrm{pH} 5$ night, when gut-passage time is constantly 30 min, initially a large amount of calcite is dissolved rather than excreted, producing a spike in DIC and total alkalinity at daybreak. Note that this extra dissolution is the key difference compared to the model run in which grazing was not restricted to the nighttime period (Fig. 2). Results are given in Table 4 and Fig. 5. Because of the long daytime nongrazing interval, the dissolution efficiency is somewhat higher than in the model runs in which feeding was not restricted to the nighttime. The maximum dissolution at $\mathrm{pH} 5$ was $\sim 27 \%$, compared to $\sim 23 \%$ with $24 \mathrm{~h}$ grazing. Penry \& Frost (1990) suggested that egestion might be modelled better as a discontinuous process. However, an appropriate formulation in the model did not significantly change the results: maximum dissolution at $\mathrm{pH} 5$ was $\sim 28 \%$ compared to $\sim 27 \%$ with continuous egestion.

\section{Critical parameters}

Adopting the measurements of Pond et al. (1995), who found high $\mathrm{pH}$ values during grazing and low $\mathrm{pH}$ values in starved individuals of Calanus helgolandicus, slightly lowered the amount of calcite dissolution. Model runs with $\mathrm{pH} 8$ during grazing and $\mathrm{pH} 6$ or 5 in non-grazing intervals both gave significant dissolution. However, a combination of $\mathrm{pH} 8$ and 7 as measured by Pond et al. (1995) in C. helgolandicus, merely yielded $1.3 \%$ dissolution of the ingested calcite.

\section{Night-time feeding}

Copepods are commonly observed to undergo diurnal vertical migration from the top of the surface mixed layer at night to depth during daytime, with up to $100 \mathrm{~m}$ depth difference (Mauchline 1998). Atkinson et al. (1996) investigated a zooplankton community in the Polar Frontal Zone and found that all 9 copepod species examined restricted their grazing to the $8 \mathrm{~h}$ night-time period. Thus, we performed model runs with various grazing/non-grazing interval lengths for a period of $8 \mathrm{~h}$, following a starvation interval of $16 \mathrm{~h}$. An example is shown in Fig. 4. At the end of the nighttime period, a grazing cycle had just finished, so calcite standing stock was at its maximum. It then decreased to zero during the day, since daytime length $(16 \mathrm{~h})$ is significantly longer than gut-passage time $(4 \mathrm{~h})$. However, as gutevacuation rate is lower during the day than at
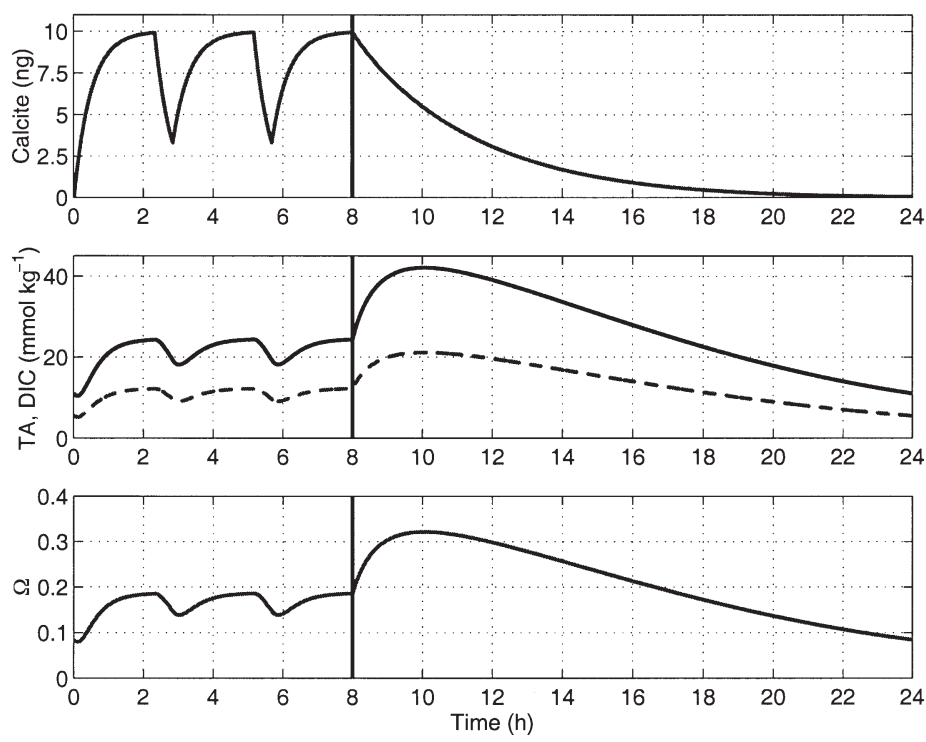

Fig. 4. Alternating grazing/non-grazing modes restricted to $8 \mathrm{~h}$ nighttime feeding period, followed by $16 \mathrm{~h}$ starvation. $\mathrm{pH}$ set at 6 , and length of grazing/non-grazing cycle $=140 / 30 \mathrm{~min}$. Further details as in Fig. 2 
Table 4. Fraction (\%) of calcite dissolved as a function of grazing $(\mathrm{G}, \mathrm{min})$ and non-grazing $(\mathrm{N}-\mathrm{G})$ interval length. Feeding restricted to $8 \mathrm{~h}$ night-time period. Standard parameter values used, with $\mathrm{pH} 6$ and 5. Gut-passage time $=30 \mathrm{~min}$ during grazing and maximal $4 \mathrm{~h}$ during non-grazing

\begin{tabular}{|crrrr|}
\hline N-G & $\mathrm{G}=60$ & $\mathrm{G}=120$ & $\mathrm{G}=180$ & $\mathrm{G}=240$ \\
\hline 30 min & & & & \\
pH 6 & 5.8 & 5.3 & 5.1 & 5.0 \\
pH 5 & 10.6 & 10.1 & 10.2 & 10.1 \\
60 min & & & & \\
pH 6 & 6.3 & 5.6 & 5.1 & 5.2 \\
pH 5 & 11.6 & 11.3 & 9.8 & 10.6 \\
90 min & & & & \\
pH 6 & 7.5 & 6.1 & 5.4 & 5.4 \\
pH 5 & 14.8 & 12.5 & 10.8 & 11.0 \\
$\begin{array}{c}\text { 120 min } \\
\text { pH 6 }\end{array}$ & 7.7 & 6.1 & 5.5 & 5.5 \\
pH 5 & 15.4 & 12.1 & 11.5 & 11.5 \\
\hline
\end{tabular}

son (1988) gave times of between 15 and 50 min for a temperature range of 5 to $25^{\circ} \mathrm{C}$. The volume of the gut is critical in that it determines how strongly concentrations of dissolved substances are changed by dissolution of certain amounts of calcite. In a small gut, calcite dissolution drives the gut's chemical system into supersaturation more easily, counteracting continued dissolution. The dissolution-rate order of calcite is not well defined, as model and experimentally-derived values range between 1 (Hales \& Emerson 1997) and 5 (Keir 1980). Fig. 1 shows the amount of biogenic carbonate that can dissolve in $30 \mathrm{~min}$ as the rate order is varied.
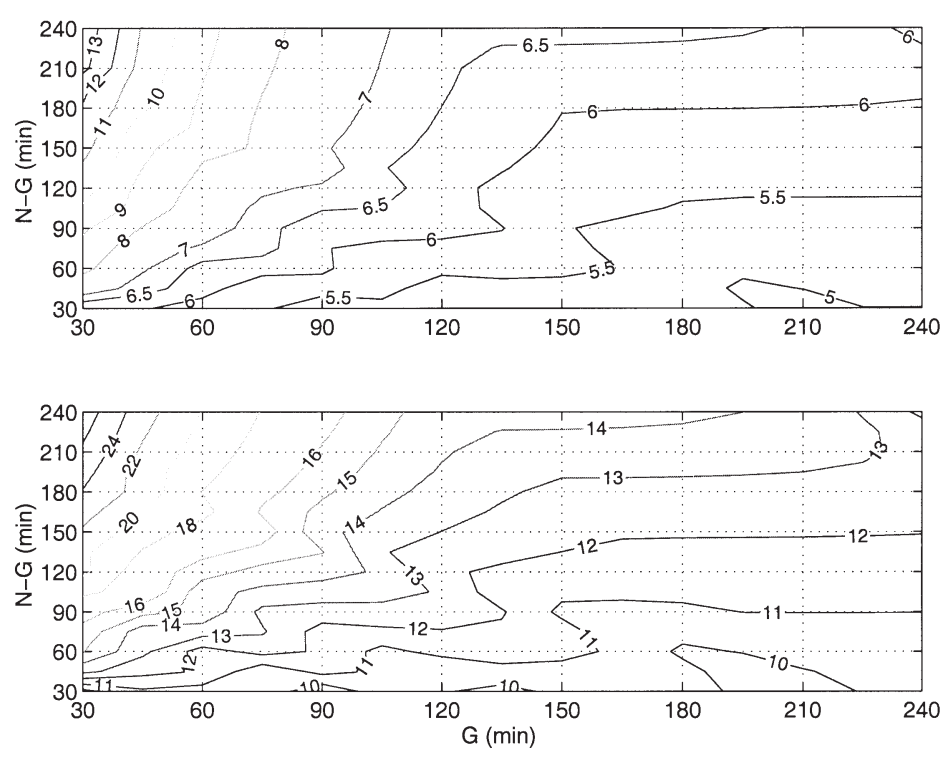

Fig. 5. Fraction (\%) of ingested calcite dissolved as a function of grazing (G) and non-grazing (N-G) interval length. Feeding restricted to $8 \mathrm{~h}$ night time period. Constant $\mathrm{pH}$ : top graph $=\mathrm{pH} 6$, bottom graph $=\mathrm{pH} 5$
Even under the most favourable circumstances (low saturation and fast dissolution), not more than $10 \%$ of the ingested calcite can be expected to dissolve. This calculation represents an upper limit for carbonate dissolution, since effects of released $\mathrm{CO}_{3}{ }^{2-}$ on saturation have not considered, but are taken into account in the model. On the other hand, prolonged gut-passage times are likely during non-grazing intervals (Atkinson et al. 1996, Irigoien 1998), enhancing the potential of $\mathrm{CaCO}_{3}$ dissolution in zooplankton guts. Thus, during alternating grazing and non-grazing cycles, the length of the non-grazing cycle is the critical parameter.

\section{Contribution to calcite water column dissolution}

To estimate how much of the calcite dissolution observed in the water column is attributable to the mechanism proposed here, the community grazing pressure of copepods such as Calanus spp. on coccolithophorid blooms must be considered. Grazing pressure is defined as that fraction of either standing stock or daily primary production of a coccolithophorid bloom grazed by the copepod community. If not stated otherwise, grazing pressure refers to standing stock. Although numerous studies have been made on copepod grazing pressure on diatom- or flagellate-dominated blooms (Bautista \& Harris 1992, Bautista et al. 1992, Thibault et al. 1999), to the authors' knowledge, no field work on copepod community grazing of coccolithophorids is available. Thus, we estimated Calanus spp. standing stock and calculated grazing pressure by measuring ingestion rates. Head et al. (1998) investigated a bloom of Emiliania huxleyi in the northern North Sea, and observed C. finmarchicus and E. huxleyi concentrations of 428 ind. $\mathrm{m}^{-3}$ and $2.24 \times 10^{9}$ cells $\mathrm{m}^{-3}$ respectively, with 1 coccolithophorid cell containing on average $12 \mathrm{pg} \mathrm{C}$ as calcium carbonate and $90 \mathrm{pg} \mathrm{C}$ as organic carbon. Assuming an ingestion rate of $10 \mu \mathrm{g} \mathrm{C}$ ind. ${ }^{-1} \mathrm{~d}^{-1}$ of organic carbon leads to a community grazing pressure of $2.1 \% \mathrm{~d}^{-1}$. This is comparable to observed grazing pressures on diatom blooms, which range up to $10 \%$ with a mean of 3 to $5 \%$ (Bautista et al. 1992, Bautista \& Harris 1992, Thibault et al. 1999). However, as Nejstgaard et al. (1997) raised the question as to whether copepod grazing rates on small algae have been underestimated in field studies due to methodological problems, copepods may have a larger impact on coccolithophorids than previously thought, making this calculation a conservative one. Assuming $15 \%$ of the 
ingested calcite to be dissolved during gut-passage, Calanus spp. grazing thus may remove less than $1 \%$ of the calcite standing stock per day. Hence, this mechanism appears unable to contribute significantly to water-column dissolution during a bloom. In a postbloom situation, however, grazing pressure is likely to be considerably higher, since microzooplankton exert the largest grazing pressure on coccolithophorid blooms, with copepods arriving later, and feeding on the microzooplankton. During a summer bloom in the northeastern Atlantic Ocean, Burkill et al. (1993) reported a grazing pressure of microzooplankton accounting for between 39 and $115 \%$ of the production of the phytoplankton (which consisted of large size fractions dominated by diatoms and coccolithophorids: Joint et al. 1993) compared to a 1 to $2 \%$ grazing pressure of copepods. As there is evidence that microzooplankton are grazed by copepods (Sherr et al. 1986), coccoliths may eventually end up in copepod guts: presumably they cannot dissolve in microzooplankton guts, whose volume is so small that supersaturation is attained at very small amounts of dissolved calcite. Slagstad et al. (1999) reported annual mesozooplankton grazing pressures on primary production in the Bering Sea Shelf and the Northern Norwegian Shelf of between 16 and $41 \%$, to be mediated by microzooplankton, and recently Hansen et al. (2000) observed a copepod grazing pressure of $100 \%$ on primary production in a mesocosm experiment. Furthermore, with decreasing food availability, the importance of reingestion of faecal pellets ('coprophagy': Frankenberg \& Smith 1967, Bathmann et al. 1987, Lampitt et al. 1990) increases. A pellet may be recycled 5 to 10 times through a copepod gut (Noji \& Estep 1991). In this way, even low dissolution fractions add up to significant amounts. If a faecal pellet loses $5 \%$ of its calcite content during gut-passage, it has lost 23 and $41 \%$ of its carbonate after 5 and 10 gut-passages respectively. Dissolution of $10 \%$ of the calcite in 1 gut-passage corresponds to $65 \%$ loss after 10 gut-passages. Thus, we can make the following calculation for a post-bloom situation: with $20 \%$ calcite dissolving during gut-passage, $70 \%$ of the ingested calcite would be lost after 5 passages; assuming a grazing pressure of $20 \%$, this would mean that $14 \%$ of the calcite standing stock would be removed in this way. This corresponds to $23 \%$ of the calcite loss observed by Milliman et al. (1999).

\section{Conclusions}

The proposed model demonstrates that carbonate dissolution in zooplankton guts is possible. When grazing is continuous, model results yield no significant dissolution. Thus, we cannot reproduce the high amounts of dissolution (up to $73 \%$ ) observed by Harris (1994) under the assumption of constant grazing. The most likely scenario, however, involves alternating grazing and non-grazing periods. This approach yields dissolution fractions of up to $\sim 25 \%$ with or without feeding restricted to the nighttime period. The potential for calcite dissolution increases with increasing length of non-grazing cycles. The most critical parameter is gut $\mathrm{pH}$, as only $\mathrm{pH}$ values less than 6.5 lead to significant dissolution. Since $\mathrm{pH}$ data to date are very limited, it may well be that gut $\mathrm{pH}$ is much lower than measured by Pond et al. (1995). The parameters of calcite dissolution kinetics were taken from experiments by Keir (1980) on complete coccoliths. As it is likely that the coccoliths are broken during ingestion or mechanical action inside the gut, dissolution should be somewhat more effective, and hence our data are probably conservative. In bloom situations, community grazing pressure of copepods seems to be too low to significantly contribute to water-column calcite dissolution. However, in pre- or post-bloom situations, grazing pressure is assumed to be higher, including grazing on microzooplankton and consumption of faecal pellets, giving rise to $\sim 14 \%$ of standing stock calcite dissolved in copepod guts. Compared to $\mathrm{CaCO}_{3}$ dissolution in the upper water column on the order of $60 \%$ as reported by Milliman et al. (1999), we conclude that dissolution of calcite in copepod guts does not account for the bulk of observed carbonate loss in the water column, but may constitute a significant portion. Other mechanisms may include localized acid production by bacteria (Troy et al. 1997) or dissolution fuelled by organic carbon remineralization in marine snow aggregates (Jansen et al. unpubl. data). However, further measurements on gut $\mathrm{pH}$, ingestion rates and grazing pressure in the field are needed to better define the numerical results of the model presented here, as well as to extend the model to include other zooplankton known to feed on coccolithophorids, e.g., pelagic tunicates (Urban et al. 1992, 1993).

Acknowledgements. We thank Peter Westbroek, Uli Bathmann, Bettina Meyer-Harms, Marcia Gowing and Ulf Riebesell for valuable discussions. The manuscript has benefited from critical reviews by 4 anonymous referees.

\section{LITERATURE CITED}

Atkinson A, Ward P, Murphy EJ (1996) Diel periodicity of subantarctic copepods: relationships between vertical migration, gut fullness and gut evacuation rate. J Plankton Res 18(8):1387-1405

Bathmann UV, Noji TT, Voss M, Peinert R (1987) Copepod fecal pellets: abundance, sedimentation and content at a permanent station in the Norwegian Sea in May/June 1986. Mar Ecol Prog Ser 38:45-51 
Bautista B, Harris RP (1992) Copepod gut contents, ingestion rates and grazing impact on phytoplankton in relation to size structure of zooplankton and phytoplankton during a spring bloom. Mar Ecol Prog Ser 82:41-50

Bautista B, Harris RP, Tranter PRG, Harbour D (1992) In situ copepod feeding and grazing rates during a spring bloom dominated by Phaeocystis sp. in the English Channel. J Plankton Res 14(5):691-703

Båmstedt U, Nejstgaard JC, Solberg PT (1999) Utilisation of small-sized food algae by Calanus finmarchicus (Copepoda, Calanoida) and the significance of feeding history. Sarsia 84:19-38

Burkill PH, Edwards ES, John AWG, Sleigh MA (1993) Microzooplankton and their herbivorous activity in the northeastern Atlantic Ocean. Deep-Sea Res Part II Top Stud Oceanogr 40(1/2):479-493

Cowles TJ, Strickler JR (1983) Characterization of feeding activity patterns in the planktonic copepod Centropages typicus Krøyer under various food conditions. Limnol Oceanogr 28:106-115

Dagg MJ, Frost BW, Walser WE Jr (1989) Copepod diel migration, feeding, and the vertical flux of pheopigments. Limnol Oceaonogr 34(6):1062-1071

Dam HG, Peterson WT (1988) The effect of temperature on the gut clearance rate constant of planktonic copepods. J Exp Mar Biol Ecol 123:1-14

Davis CS, Gallager SM, Marra M, Stewart WK (1996) Rapid visualization of plankton abundance and taxonomic composition using the video plankton recorder. Deep-Sea Res Part II Top Stud Oceanogr 43(7-8):1947-1970

Fagerbakke KM, Heldal M, Norland S, Heimdal BR, Båtvik H (1994) Emiliania huxleyi. Chemical composition and size of coccoliths from enclosure experiments and a Norwegian Fjord. Sarsia 79:349-355

Frankenberg D, Smith LF Jr (1967) Coprophagy in marine animals. Limnol. Oceanogr. 12:443-450

Gallager SM, Davis CS, Epstein AW, Solow A, Beardsley RC (1996) High-resolution observations of plankton spatial distributions correlated with hydrography in the Great South Channel, Georges Bank. Deep-Sea Res Part II Top Stud Oceanogr 43(7-8):1627-1663

Greene $\mathrm{CH}$, Wiebe $\mathrm{PH}$, Pelkie C, Benfield MC, Popp JM (1998) Three-dimensional acoustic visualization of zooplankton patchiness. Deep-Sea Res Part II Top Stud Oceanogr 45:1201-1217

Hales B, Emerson S (1997) Evidence in support of first-order dissolution kinetics of calcite in seawater. Earth Planet Sci Lett 148:317-327

Hansen BW, Hygum BH, Brozek M, Jensen F, Rey C (2000) Food web interactions in a Calanus finmarchicus dominated pelagic ecosystem-a mesocosm study. J Plankton Res 22(3):569-588

Harris RP (1994) Zooplankton grazing on the coccolithophore Emiliania huxleyi and its role in inorganic carbon flux. Mar Biol 119:431-439

Head RN, Crawford DW, Egge JK, Harris RP, Kristiansen S, Lesley DJ, Marañón E, Pond D, Purdie DA (1998) The hydrography and biology of a bloom of the coccolithophorid Emiliania huxleyi in the northern North Sea. J Sea Res 39:255-266

Honjo S, Roman MR (1978) Marine copepod faecal pellets: production, preservation and sedimentation. J Mar Res 36(1):45-57

Huskin I, Anadón R, Álvarez-Marqués F, Harris RP (2000) Ingestion, faecal pellet and egg production rates of Calanus helgolandicus feeding coccolithophorid versus non-coccolithophorid diets. J Exp Mar Biol Ecol 248:239-254
Irigoien X (1998) Gut clearance rate constant, temperature and initial gut contents: a review. J Plankton Res 20(5): 997-1003

Ishimaru T, Nishida S, Marumo R (1988) Food size selectivity of zooplankton evaluated from the occurrence of coccolithophorids in the guts. Bull Plankton Soc Jpn 35(2): 101-114

Jumars PA, Penry DL (1989) Digestion theory applied to deposit feeding. In: Lopez G, Taghon G, Levinton J (eds) Ecology of marine deposit feeders. Springer-Verlag, Berlin, p 114-128

Joint I, Pomroy A, Savidge G, Boyd P (1993) Size-fractionated primary productivity in the northeast Atlantic in May-July 1989. Deep-Sea Res Part II Top Stud Oceanogr 40(1/2): 423-440

Keir RS (1980) The dissolution kinetics of biogenic calcium carbonates in seawater. Geochim Cosmochim Acta 44: 241-252

Lalli CM, Parsons TR (1993) Biological oceanography: an introduction. Pergamon Press, Oxford

Lampitt RS, Noji T, von Bodungen B (1990) What happens to zooplankton faecal pellets? Implications for material flux. Mar Biol 104:15-23

Mackas DL, Burns KE (1986) Poststarvation feeding and swimming activity in Calanus pacificus and Metridia pacifica. Limnol Oceanogr 31(2):383-392.

Mauchline J (1998) The biology of calanoid copepods. In: Blaxter JHS, Southward AJ, Tyler PA (eds) Advances in marine biology. Academic Press Ltd, London, p 439-443

Mayzaud P (1986) Digestive enzymes and their relation to nutrients. In: Corner EDS, O'Hara SCM (eds) The biological chemistry of marine copepods. Clarendon Press, Oxford, p 226-259

Mayzaud P, Mayzaud O (1981) Kinetic properties of digestive carbohydrases and proteases of zooplankton. Can J Fish Aquat Sci 38:535-543

Millero FJ (1995) Thermodynamics of the carbon dioxide system in the oceans. Geochim Cosmochim Acta 59:661-677

Milliman JD, Troy PJ, Balch WM, Adams AK, Li YH, Mackenzie FT (1999) Biologically mediated dissolution of calcium carbonate above the chemical lysocline? Deep-Sea Res I 46:1653-1669

Nejstgaard JC, Witte HJ, van der Wal P, Jacobsen A (1994) Copepod grazing during a mesocosm study of an Emiliania huxleyi (Prymnesiophyceae) bloom. Sarsia 79:369-377

Nejstgaard JC, Båmstedt U, Bagøien E, Solberg PT (1995) Algal constraints on copepod grazing. Growth state, toxicity, cell size, and season as regulating factors. ICES J Mar Sci 52:347-357

Nejstgaard JC, Gismervik I, Solberg PT (1997) Feeding and reproduction by Calanus finmarchicus, and microzooplankton grazing during mesocosm blooms of diatoms and the coccolithophore Emiliania huxleyi. Mar Ecol Prog Ser 147:197-212

Noji TT, Estep KW (1991) Image analysis of faecal material grazed upon by three species of Copepods: evidence for coprorhexy, coprophagy and coprochaly. J Mar Biol Assoc UK 71:465-480

Norrbin MF, Davis CS, Gallager SM (1996) Differences in fine-scale structure and composition of zooplankton between mixed and stratified regions of Georges Bank. Deep-Sea Res Part II Top Stud Oceanogr 43(7-8): 1905-1924

Penry DL, Frost BW (1990) Re-evaluation of the gut-fullness (gut fluorescence) method for inferring ingestion rates of suspension-feeding copepods. Limnol Oceanogr 35: 1207-1214 
Penry DL, Jumars PA (1986) Chemical reactor analysis and optimal digestion. BioScience 36(5):310-315

Pilskaln CH, Honjo S (1987) The fecal pellet fraction of biogeochemical particle fluxes to the deep sea. Glob Biogeochem Cycles 1(1):31-48

Pond DW, Harris RP, Brownlee C (1995) A microinjection technique using a $\mathrm{pH}$-sensitive dye to determine the gut pH of Calanus helgolandicus. Mar Biol 123:75-79

Rosenberg GG (1980) Filmed observations of filter feeding in the marine planktonic copepod Acartia clausii. Limnol Oceanogr 25:738-741

Sherr EB, Sherr BF, Paffenhöfer GA (1986) Phagotrophic protozoa as food for metazoans: a 'missing' trophic link in marine food webs. Mar Microb Food Webs 1:61-80

Slagstad D, Tande KS, Wassmann P (1999) Modelled carbon fluxes as validated by field data on the north Norwegian shelf during the productive period in 1994. Sarsia 84: 303-317

Takahashi T, Broecker WS, Bainbridge AE (1981) Supplement to the alkalinity and total carbon dioxide concentration in the world oceans. In: Bolin B (ed) Carbon cycle modelling. Scientific Committee on Problems of the Environment (SCOPE). John Wiley \& Sons, New York, p 159-199

Thibault D, Roy S, Wong CS, Bishop JK (1999) The downward flux of biogenic material in the NE subarctic Pacific: importance of algal sinking and mesozooplankton her-

Editorial responsibility: Otto Kinne (Editor),

Oldendorf/Luhe, Germany bivory. Deep-Sea Res Part II Top Stud Oceanogr 46(11/12): 2669-2697

Troy PJ, Li YH, Mackenzie FT (1997) Changes in surface morphology of calcite exposed to the oceanic water column. Aquat Geochem 3:1-20

Urban JL, McKenzie CH, Deibel D (1992) Seasonal differences in the content of Oikopleura vanhoeffeni and Calanus finmarchicus faecal pellets: illustrations of zooplankton food web shifts in coastal Newfoundland waters. Mar Ecol Prog Ser 84:255-264

Urban JL, McKenzie CH, Deibel D (1993) Nanoplankton found in fecal pellets of macrozooplankton in coastal Newfoundland waters. Bot Mar 36:267-281

van der Wal P, Kemper RS, Veldhuis MJW (1995) Production and downward flux of organic matter and calcite in a North Sea bloom of the coccolithophore Emiliania huxleyi. Mar Ecol Prog Ser 126:247-265

Walter LM, Morse JW (1985) The dissolution kinetics of shallow marine carbonates in seawater: a laboratory study. Geochim Cosmochim Acta 49:1503-1513

Watabe N, Kingsley RJ (1990) Extra-, inter-, and intracellular mineralization in invertebrates and algae. In: Crick RE (ed) Origin, evolution, and modern aspects of biomineralization in plants and animals. Plenum Press, New York and London, p 209-223

Zeebe RE, Wolf-Gladrow DA (2001) $\mathrm{CO}_{2}$ in seawater: equilibrium, kinetics, isotopes. Elsevier, Amsterdam

Submitted: July 14, 2000; Accepted: February 15, 2001

Proofs received from author(s): September 27, 2001 